\title{
Do Institutions Quality Affect FDI Inflows in Sub-Saharan African Countries?
}

\author{
Komlan Fiodendji ${ }^{1}$ and Kodjo Evlo ${ }^{2}$
}

\begin{abstract}
This paper investigates the linkages between natural resources, institutional quality and FDI, and the interaction impact of natural resources and institutional quality on FDI. It argues that countries highly ranked with respect to institutional quality tend to do better in attracting FDI. In an empirical analysis using different econometric techniques and a data sample of 30 African Sub-Saharan countries for the period 1984-2007, the paper finds that different aspects of a country's institutional quality are almost always significant, regardless of the other control variables used in the least-squares and instrumental variables estimations.

Taking into account the interaction impact, the paper finds that when the quality of a host country's institutions is sufficiently low, further deterioration in this variable may not stimulate FDI inflows; it may instead reduce them. However, FDI inflows increase significantly when institutional quality improves. The paper also finds that the marginal effect of natural resources on FDI increases with resource abundance while institutional quality remains a factor. Interaction between the two factors is determinant in countries' ability to compete for FDI inflows.
\end{abstract}

JEL classification numbers: F23, D72

Keywords: Foreign direct investment, Institutional quality, natural resources

\section{Introduction and Motivation}

During last decade, the literature dedicated to the theory of economic development has evolved, with a new focus on the quality of domestic institutions as a key determinant of cross-country differences in both growth rate and income per capita. Voice and

\footnotetext{
${ }^{1}$ Contact Person, Instructor, Department of Economics, Université de Montréal, Montreal, Qc, Canada.

${ }^{2}$ Associate Professor of Economic, Université de Lomé, Lome, Togo
}

Article Info: Received : September 8, 2014. Revised : October 4, 2014. Published online : January 1, 2015 
accountability, political stability and lack of violence, government effectiveness, regulatory quality, rule of law and low level of corruption are shown to be highly correlated with growth (Edison et al., 2003). There also has been an increasing interest in the determinants of foreign direct investment (FDI) in developing countries. Several empirical studies reveal the role played by FDI as a major constituent of capital flows in these countries.

Moreover, capital flows relax the constraints on mobilization of resources for a country; they generate the exchange of technological and organizational knowledge; and they can cause institutional change. Hence, capital flows represent additional resources a country needs to improve its economic performance and they provide both physical capital and employment possibilities that may not be needed in the host market. Not surprisingly, a number of authors have also studied the link between institutional quality and FDI (see Busse and Hefeker, 2007; Kostevc et al., 2007 etc.). FDI is now a large share of capital formation in many poor countries; therefore, the FDI-promoting effects of good institutions may be an important channel for their overall effect on growth and development.

Poorly regulated institutions and/or complete lack of institutional governance impinge additional costs on the wellness to invest in SSA countries (Wei, 2000). The high sunk costs associated with investing offshore, along with the uncertainty associated with poor physical and financial infrastructure along with weak enforcement of regulations and ineffective legal systems, have progressively forced companies to be increasingly selective as to where to invest. As Vittorio and Ugo (2006) point out, it is clear that institutions may affect FDI inflows through three potential channels. Firstly, the presence of good institutions tends to improve factor productivity and subsequently stimulates investments, regardless domestic or external. Secondly, good institutions will result in a reduction in investment related transaction costs (i.e. corruption-related costs). Finally, and by definition, FDI is generally associated with high sunk costs. Therefore, good institutions (i.e. proper property right enforcement, effective legal systems) enhance the quality of business environment and give multinational firms the security they need.

To attract and increase investments in productive capital, countries must continue to endeavour to create a transparent, stable and foreseeable business environment, equipped with mechanisms for the implementation of adequate contracts and for the respect of property rights. Such environment must arise from sound macroeconomic policies goods conceived and effective institutions favorable to both national and international firm ${ }^{3}$.

Thus, it is essential to improve the principal aspects in order to influence the choices of establishment of the investment. That requires identifying these factors, which can differ from an area to another, taking into account specificities and the potentialities relative to each one of it. This study asks the following question: what are the determinants of FDI flows? Generally, these factors could be separated into two categories: (i) economic factors and, (ii) institutional factors, i.e., factors that have to do with regulatory, bureaucratic, political and judicial environment.

In fact, the institutional quality of a host country received growing attention in the recent literature as one of the key determinants in location decisions made by foreign firms.

\footnotetext{
${ }^{3}$ See Note Secretariat on the Adoption of the Consensus of Monterrey of the United Nations (Draft conclusion and decisions of the International Conference on the financing of the development), March 1st, 2002.
} 
Institutions provide the incentive structure for exchange that determines the cost of transaction and the cost of transformation in an economy (North, 1990). As an environment for investment, institutional variables such as the legal and political systems are thought to be crucial in affecting economic performance through their effect on investment decisions by curbing the risk of opportunism. This may be a particularly important issue for foreign investors who are not familiar with 'the rules of the game in a society' (Alfaro et al., 2005). Less corruption and a fair, predictable, efficient bureaucracy may help attract FDI (Campos and Kinoshita, 2003).

The majority of papers on this topic provide evidence in support of a positive effect of the role of institutions in entry decisions by multinational enterprises (MNE). Campos and Kinoshita (2003) show that quality of institutions is one of the main determinants of FDI inflows to transition countries. Based on the analysis of panel data in developing countries, Gastanaga et al. (1998) demonstrate the direct effect of institutional characteristics on FDI.

Several studies exist on the determinants of FDI in Sub Saharan African (SSA) ${ }^{4}$. A common perception of all these studies is that FDI to Africa is driven by availability of natural resources, mainly solid minerals and crude oil. This has severe policy implications. If this is true, then FDI in the region is largely determined by an uncontrollable factor. In addition, it suggests that countries that do not have natural resources will attract very little or no FDI regardless of the policies they adopt (Asiedu, 2005).

Most of these studies argued that good institutions may have a positive impact on FDI outflows because they create favourable conditions for multinational companies to emerge and invest abroad. However, none of these studies has attempted to examine how the importance of these institutions varies depending on the characteristics of countries in the sample (oil exporters, non-oil exporters or countries rich or not in natural resources). For these reasons, this paper considers in particular the effects of the second category of factors, that is, the effects of the quality of the host country's institutional environment on the inflows of FDI. Specifically, the present paper attempts to investigate the institutional quality impact on FDI by asking the following questions: Do institutional characteristics (as identified with indicators such as corruption, bureaucratic delays, rule and law, investment profile index, political stability, government effectiveness, internal and external conflicts) affect FDI inflows? If institutions do matter, what is the nature of the relationship between FDI movements and institutions' quality? Are there systematic differences across countries based on the quality of their institutions? In other words, how countries characteristics influence the relationship between government policies, institutions, and FDI inflows? Is the marginal effect of natural resources on FDI dependent on the host country's institutional quality? In other words, does the effect of natural resources on FDI also depend on the host country's institutions quality?

To address these questions, with respect to the panel analysis, we apply panel data analysis technique namely fixed effects models and random effects specification. This approach allows us to distinguish more systematically between the effects of policy changes and other less variable elements of the investment climate on FDI over time as well as across countries.

${ }^{4}$ See, for example, Asiedu (2002, 2003, 2005); Morrisset (2000); Schoeman et al (2000); Cheng (2000); Chakrabarti (2001); Kinoshita and Campos (2004); Ajayi (2007). 
The remainder of the paper is organized as follows. In section 2, we review and discuss briefly the literature. Section 3 introduces the data description and the model specification employed in our empirical application. In Section 4 the empirical results are presented. The concluding section, section 5, summarizes our contribution to the literature and discusses future research avenues.

\section{Literature Review}

\subsection{Theoretical Framework}

There are several theories attempting to explain why firms engage in transnational production, which is an effect of FDI. Faeth (2008) presents nine theoretical models of FDI. However, there is no clear-cut theory of the determinants of FDI flows, especially in developing countries. Equally, the traditional theories of development, which lay important emphasis on international trade and exchange of capital, have come under severe criticism over the years.

The first of these theories is the neoclassical microeconomic theory. It was the dominant theory used to explain reasons for FDI inflows until the 1960s (Dunning 1993). According to this neo-classical microeconomic theory, capital movements are caused by the differences in interest rates that exist between countries. From the view of this neo-classical theory, capital is a commodity, thus its price determines its supply as well as its demand and allocation. In this case, capital, according to the neo-classical analysis, is determined by the interest rate (Aggarwal 1984).

Capital will thus flow freely from countries with low rates of return to those with relatively high rates of return under conditions of perfect competition (Iverson 1953). The limitation of this theory according to its critics is its inability to explain the role of trans-national corporations (TNCs) in capital mobility because it limits itself to explaining how and where firms decide to obtain the capital needed to finance their global plans. Critics also hold the view that because the theory does not say anything about the purpose of its investment, i.e. either for managerial control or production capabilities, its role in modern times is thus suited only to the explanation of portfolio investments rather than FDI.

Another theory of FDI is that of the intangible capital approach. According to this theory, the possession by a firm of specific 'monopolistic advantages 'or 'intangible assets' is a sine qua non for its overseas production (Lall 1980). These advantages may include production techniques, managerial skills, industrial organisation, and knowledge of the product as well as the factor markets. The theory outlines three useful purposes, which these advantages must serve. First, these advantages must provide a competitive edge to the firm concerned and they must outweigh those of foreign rivals as well as those in the prospective country in which it plans to invest. Second, the monopolistic advantage that the firm possesses must be transferable abroad and should be employed most economically at the foreign location. Thirdly, the firm itself must profit from the exploitation of these advantages rather than licensing or selling them out to an independent firm.

Rugman (1986) proposes another explanation based on internalization theory. This theory examines FDI from the point of view of a need to internalize transaction costs in order to improve profitability and to explain the emergence of FDI effectiveness (Banga, 2003). 
During the past decade, world economy became increasingly integrated with, consequently, a significant rise in FDI (Busse, 2004). However, these theories were not capable to explain, to a certain extent, why the foreign investors choose to place their assets in a country rather than another and, particularly, they do not provide adequate explanation of the marginalization of the African continent. Actually, several determinants were identified through the literature. One distinguishes mainly traditional determinants including economic factors and social determinants such as the ones based on human capital. Recent studies emphasize the need to improve and support advantages in host countries by the incentive role their governments play. Following these studies, the debate on the choice of FDI establishment is now evolving around the quality of institutions as another important determinant.

\subsection{Empirical Approach: Institutions and FDI}

The debate over the role of institutions in economic development catches researcher's attention. Since the late 1990s, a growing interest has emerged in studying the links between institutions and FDI. Good institutions are supposed to exert a positive influence on development through the promotion of investment in general. FDI represents a considerable part of capital formation in developing countries (UNCTAD, 2004); an interesting question, therefore, is to examine the role of good institutions in promoting FDI. According to Sachs (2003), the concept of institutions became the intermediate goal of any economic reforms. It emerges from recent studies (Rodrik, 1999; Acemoglu et al., 2001; Easterly and Levine, 2002; Sachs, 2003; Glaeser et al., 2004) that economic development of a country is explained mainly by its institutions, resources, economic policies, geography and geopolitics. Several empirical studies reveal the importance of institutions through FDI behaviour models (Acemoglu et al., 2001 and 2003; Asiedu, 2003 and 2005; Banga, 2003; Busse, 2003; Glaeser et al., 2004). Rodrik (1997) emphasizes the fact that institutional quality explains the growth and FDI gaps between East Asian countries and African countries better than traditional economic factors (capital accumulation, technical progress, and rise in labour supply). Chan and Gemajel (2003) also emphasize that factors like political stability, institutional quality, lack of internal and external conflicts, low level of corruption, lack of bureaucracy, trade liberalization and an attractive business environment attract foreign investors. Hall and Jones (1999), from a sample of 133 countries, reveal that institutions promoting production and private property stimulate human and physical capital accumulation and, consequently, increase the total factor productivity and the domestic product. Concerning institutional quality in Africa, a study on 23 African countries draws up a negative evaluation which suggests that institutions in Africa have not yet progressed sufficiently to contribute significantly to development (Nsouli, 2000). Other studies, such as that of Asiedu (2003) related to 22 SSA countries, reveal that effectiveness of institutions, political and economic stability and low level of corruption encourage private capital inflows.

Several contributions have focused on the role of institutions in locating FDI, for example Wheeler and Mody (1992) find that a composite index of risk factors, which include bureaucratic red tape, political instability, corruption and quality of the legal system, has no significant influence in determining the location of US foreign affiliates. However a composite index lumps together several institutional variables with other variables such as risk of terrorism, living environment of expatriates, inequality etc, which are not directly 
related to the quality of institutions. Wei $(1997,2000)$ uses data on bilateral FDI stocks from OECD countries and finds that corruption, as well as uncertainty regarding corruption, has a significant negative effect on FDI.

Globerman and Shapiro (1999) argue that good institutions may have a positive impact on FDI outflows because they create favourable conditions for multinational companies to emerge and invest abroad. Globerman and Shapiro (2002) estimate the impact of governance indicators developed by Kaufman et al. (1999a, b) on both inflows and outflows of FDI. They find that good governance impacts positively both on FDI inflows and outflows, although the latter effect is only significant for relatively big and developed countries.

One major limitation of these studies is that the empirical results do not incorporate bilateral parameters where, for example, institutional quality variables in both the source country and the host country are not included simultaneously. Thus, it is not possible to rank the importance of governance in the source country compared to that of the host country.

Recently, several researchers have studied the impact of institutions on FDI inflows. While one strand of thought shows the relationship to be positive (Harms and Ursprung, 2002; Jensen, 2003; Busse, 2004), Li and Resnick (2003) argue that there is more to the relationship. Though democratic right has an indirect boosting impact on FDI inflows by improving property rights protection, the direct impact on FDI is negative. Busse and Hefeker (2005) show in their study that some aspects of political stability like government stability, the absence of internal and external conflicts, basic democratic rights and an efficient law and order system, matter significantly in determining FDI inflows. They show that foreign investors are susceptible to changes in political stability of an economy. Stein and Daude (2007) find inward FDI to be significantly influenced by the quality of institutional variables. They find that political instability and violence, government effectiveness, regulatory burden, rule of law and graft matter for FDI. However, political representation and accountability indicators have an insignificant effect on inward FDI. The International Country Risk Guide (ICRG) and La Porta et al. (1998) variables such as risk of repudiation of contracts by government, and risk of expropriation and shareholders rights are important variables when considering where to invest.

Kostevc et al. (2007) analyse the relation between foreign direct investment and the quality of the institutional environment in transition economies. The analysis confirms a significant impact of various institutional aspects on the inflow of foreign capital. To isolate the importance of the institutional environment from the impact of other factors, a panel data analysis was performed using the data of 24 transition economies in the period 1995-2002. The results show that in the observed period the quality of the institutional environment significantly influenced the level of foreign direct investment in transition economies. Other variables that proved to have a statistically significant influence were budget deficit, insider privatization, and labour cost per hour.

Busse and Hefeker (2007) explore the linkages among political risk, institutions, and foreign direct investment inflows. For a data sample of 83 developing countries covering 1984 to 2003, they identify indicators that matter most for the activities of multinational corporations. The results show that government stability, internal and external conflicts, corruption and ethnic tensions, law and order, democratic accountability of government, and quality of bureaucracy are highly significant determinants of foreign investment inflows. Wei (2000) examines a bilateral panel of FDI data and provides evidence that corruption in a host country negatively affects inward FDI particularly from U.S. and EU. 
Similarly, Aizenman and Spiegel (2000) introduce an imperfect enforcement contract framework and show that corruption discourages FDI more severely than it discourages domestic investments.

Hausmann and Fernandez Arias (2000) use the Kaufmann et al. (1999a, b) data on institutional variables and indices of creditor and shareholder rights from La Porta et al. (1997, 1998, and 1999) to study the effects on the composition of capital inflows. They find that foreign portfolio investment is more sensitive to the quality of institutions, that regulatory burden, and government effectiveness and shareholders rights have significant effects on FDI as a share of GDP.

Mody et al. (2003) finds that the proportion of FDI in comparison to portfolio investment is lower in countries where institutions are more transparent. They present empirical evidence based on an index of creditor's rights from La Porta et al. (1998) in their gravity model to explain the ratio of FDI flows to trade.

In a set of cross-country regressions, Aizenman and Spiegel (2004) find that the share of FDI to gross fixed investment as well as the ratio of FDI to private domestic investment is negatively and significantly correlated with the level of corruption and FDI is more sensitive than domestic investment to the level of institutional quality.

Three general approaches are usually adopted by the recent empirical studies to measure institutional quality (Kaufmann et al., 2002; Rodrick et al., 2002; Acemoglu et al., 2003; Asiedu, 2003; Edison, 2003; Glaeser et al., 2004; Alfaro et al., 2005): (i) the quality of the public affairs management (corruption, political rights, effectiveness of the public sector and weight of regulations); (ii) the existence of property rights and their application; (iii) constraints imposed on political leaders. However, these measures are not objective since they emanate from subjective evaluations and appreciations of national experts or from evaluations of the population collected by surveys carried out by international and nongovernmental organizations (Edison, 2003). Since institutional variables are also endogenous, Edison suggests being careful in empirical analyses especially about the causality direction. From an econometric point of view, the problem would be solving by including instrumental variables.

Rodrick et al. (2002) estimate the respective contributions of institutions, geography, and trade in determining income levels around the world, using instruments for institutions and trade. Their results indicate that once institutions are controlled for, measures of geography have at best weak direct effects on incomes, although they have a strong indirect effect by influencing the quality of institutions. Similarly, once institutions are controlled for, trade is almost always insignificant, and often enters the income equation with the wrong (i.e. negative) sign, although trade too has a positive effect on institutional quality.

Borenzstein et al. (1992) tests the effect of FDI on economic growth using cross country regressions for 69 developing countries. De Gregorio (1992) find a significant impact of FDI on growth using a panel analysis of 12 Latin American countries while Blomstrom et al (1996) find the same using a panel of least developed nations. De Mello (1996) employed both time series and cross section analysis to establish the complementarity between FDI and domestic investment. Calvo and Sanchez-Robles (2002) have delved into the interlinkages among FDI, economic freedom and economic growth. According to them, panel approach is relatively better than cross section analysis since it takes into account the variability within countries and also "allow for differences in production function of the various nations in the form of unobservable individual effects".

Several recent studies have stressed the importance of quality of institutions for economic 
development (e.g., Acemoglu et al., 2001; Hall \& Jones, 1999; Knack \& Keefer, 1995; La Porta et al., 1999; Mauro, 1995). But in many researches on the resource curse hypothesis, the institutional channel has rarely been verified with much success, although it has frequently been mentioned as an important potential determinant of the curse. Quality of institutions is often simply controlled for by using a measure of corruption (e.g., Papyrakis \& Gerlagh, 2004; Sachs \& Warner, 1995a).

Mehlum et al. (2006) show that the interaction between natural resource abundance and high-quality institutions, measured by an aggregate indicator, has a positive growth effect, while the direct negative growth effect of resource wealth seems to persist. However, these results are based on resource exports data, which pose the problems already discussed above: we contend that they more accurately depict the effects of natural resource exports dependence.

From a more qualitative angle, historians, political scientists, and economists generally agree that the presence of abundant natural resources (especially minerals) leads to rent seeking behaviour and corruption, thereby decreasing the quality of government, which in turn negatively affects economic performance. Robinson et al. (2006) develop a political economy model which shows that the impact of a "resource boom"' crucially depends on the quality of the political institutions, and in particular the degree of clientelism in the public sector. Countries with worse-quality institutions are more likely to suffer from a resource curse. There is also evidence that natural resource abundance considerably increases the potential of violent civil conflict (Collier \& Hoeffler, 2005). Empirically, rent-seeking due to natural resources has been shown to be nonlinear, both with respect to income and the total amount of resources in a country. In his cross-country study, Ross (2001) finds that the negative resource effects of mineral abundance on institutions decline with increasing income levels and with greater past mineral exports. And in their case study of Nigeria, Sala-i-Martin and Subramanian (2003, p.10) describe how "oil corrupts and excess oil corrupts more than excessively." They stress that the natural resource curse only holds for mineral-and particularly oil-abundance, and not agricultural products and food (all measured by their respective export shares).

In a different vein, Atkinson and Hamilton (2003) show that natural resource abundance may have negative effects on development when weak institutions allow resource profits to be spent in government consumption rather than investment, especially in countries with low levels of real saving. Stijns (2005) contends that there are both positive and negative channels through which natural resource abundance affects economic growth: he finds that land abundance tends to have negative effects on all determinants of growth, including different measures of institutional quality, while the effects of mineral abundance are less clear-cut.

Finally, Acemoglu et al. (2001) test the effects on current income levels of their instrumented indicator for institutions against those of natural resource abundance, measured by the country shares of world non-fuel mineral reserves and per capita oil resources. They find no significant influence of natural resource abundance at all, confirming their view that institutional quality alone can explain a great deal of cross-country differences in economic development, and implicitly questioning the natural resource curse hypothesis even further. 


\section{Model and Data Description}

This section specifies the model used in the empirical investigation of the relationship between institutions and FDI. It also provides a simple description of the data set used in the empirical investigation.

\subsection{Model Specification}

To empirically investigate the role played by institutions in determining FDI, the following simple model is used

$$
F D I_{i t}=\alpha_{i}+\beta \text { Inst }_{i t}+C V_{i t}^{\prime} \lambda+\varepsilon_{i t}
$$

Where FDI, is measured as the net foreign direct investment inflow as a percentage of GDP to take into account the effect of the country size. Inst is an indicator of institutional quality. It is constructed from the International Country Risk Guide (ICRG) which is provided by the Political Risk Services (PRS) Group. Since the beginnings of the 1980s, PRS Group has been providing information on 12 subcategories of political risk indicators that assess different aspects of institutional quality of 142 countries. The main advantage of these datasets is that they are available for a considerable time span, also allowing us to test the relevance of institutions in attracting FDI exploiting the time variation. This also enables us to control for potential unobserved heterogeneity that could bias our cross-section estimates. The variables we consider are a subset of the ones available from the ICRG database that refer to political risk. Specifically, we use the following indicators: Government Stability (stabgov), Profile Investment (profinv), Democratic Accountability (demo), Law and Order (rol), and Control of Corruption (corr). While the first two variables are assessed on a scale from 0 to 12, the last three are coded between 0 and 6; and Bureaucratic Quality (burqal) is assessed on a scale from 0 to 4. In order to facilitate comparability, as in Kaufmann et al. (1999a), we standardize all variables in our sample to mean zero and standard deviation of one. In all cases, high score equates to very low risk and low score means very high risk. In other words, higher values indicate better institutions and secure property rights. Another type of variable is political risk that is represented by two indices: internal conflict (inconf) and external conflict (exconf). The data were obtained from the International Country Risk Guide (ICRG). The sign of the coefficient is not determined a priori. Each indicator is assessed on a scale from 0 to 12 with higher values indicating less political risk and better institutions. In general, we would expect that all indicators are positively related to FDI inflows, as less political risk and better institution may attract FDI due to a lower risk. $\mathrm{CV}$ is a vector of controlling variables drawn from the empirical literature of FDI determinants.

$\alpha_{i}$ is a common fixed-effect term and $\varepsilon_{i t}$ is the disturbance term. $i$ denotes cross-section unit with $i=1,2, \ldots \ldots . ., N ; N$ is the number of countries and $t$ denotes time-periods with $t=1,2, \ldots \ldots ., T$; $T$ is number of time periods.

Choosing the set of controlling variables is to some extent problematic, because the empirical literature suggests a large number of variables as potential determinants of FDI, and while some of these are proposed by various theories of FDI, others are included because they can be linked intuitively to FDI (Moosa and Cardak, 2006). However, in this 
paper we use the following ones:

The degree of openness (do) the ratio of merchandised trade to GDP, which is used to capture the influence of trade openness on FDI with a positive sign being expected; Market Size (gdp) and the Growth rate (growth) which are used to capture the influence of market size of the host country. FDI literature documents that a market size measure is expected to have a positive impact on FDI, as a large market means a greater demand for goods and services which attracts market-seeking FDI; inflation rate (Infl), which is measured by the annual percentage change in the consumer price index. Inflation rate is used as a proxy for macroeconomic stability. Macroeconomic stability reduces the level of uncertainty encountered by investors and increases the level of confidence in the economy, which encourages FDI. The Real Exchange Rate (exchrat) could prove to be an important factor in the FDI fluctuations on the world market. It is a measure of international competitiveness. However, its impact is rather ambiguous, as the literature (both theoretical and empirical) on the issue suggests. In addition to these variables, the set of controlling variables will include other variables namely, natural resources (natres). The omission of a measure of natural resources from the estimation, especially for African counties case, may cause the estimates to be biased (Asiedu, 2002). As some of studies, we use the share of minerals and oil in total exports to capture the availability of natural resource endowments.

Thus, the model that will be used as a benchmark to assess the role played by institutions in determining FDI, takes the following form:

$$
\begin{aligned}
& F D I_{i t}=\alpha_{i}+\phi_{1} \text { Inst }_{i t}+\phi_{2} g d p_{i t}+\phi_{3} \text { growth }_{i t}+\phi_{4} d o \\
& +\phi_{5} \text { natres }_{i t}+\phi_{6} \text { inf } l_{i t}+\phi_{7} \text { exchrat }_{i t}+\varepsilon_{i t}
\end{aligned}
$$

To explain the observed non-linearity between quality of institution and FDI inflows, we introduce natural resources factor in our analysis. This helps us explored whether the levels of quality of institutions play a role in the ability of a country to use natural resource to its advantage and reap its benefits by attracting more FDI. For this we alter our regression specification (equation 2) as

$$
\begin{aligned}
& F D I_{i t}=\alpha_{i}+\phi_{1} \text { Inst }_{i t}+\phi_{2} g d p_{i t}+\phi_{3} \text { growth }_{i t}+\phi_{4} d o_{i t}+\phi_{5} \text { natres }_{i t} \\
& +\phi_{6} \text { inf } l_{i t}+\phi_{7} \text { exchrat }_{i t}+\phi_{8}(\text { Inst } * \text { natres })_{i t}+\varepsilon_{i t}
\end{aligned}
$$

\subsection{Data Description}

The empirical analysis is based on 30 SSA countries and covers the period from 1984 to 2007. A list of the countries included in the sample, and data sources for all variables used in the analysis, are presented in Appendix. The choice of countries and the time period is determined by availability of the data. All data were sampled at 5-year intervals for 25 years from 1984 to 2007, that is, 1984-1988, 1989-1993, 1994-1998, 1999-2003 and 2004-2007. Transforming data from annual observations to five-year averages has several advantages. First, it may help to limit the impact of business cycles on the estimated 
coefficient, as FDI net inflows vary widely from year to year, resulting in large fluctuations that may obscure the impact of persistent variables such as institutions on FDI. Second, averaging the data over five-year intervals reduces the number of observations with zero or negative values, which would otherwise be excluded from the regression analysis.

Table 1 gives summary statistics of the variables included in the model and Table 2 shows the correlation matrix for all the explanatory variables and the log of FDI, the dependent variable.

The correlation matrix shown in Table 2 gives a first but crude approximation of the relationship between FDI and its determinants. The table shows that FDI is positively correlated with indictors of market size, log of GDP per capita and GDP growth rate, the ratio of trade to GDP, and institutional quality. However, the Table shows that the relationship between FDI and its determinants, except inflation rate, is significant at $1 \%$ level. Furthermore, this table indicates that the relationship between FDI and indicators of openness to trade and indicators of institutional quality is particularly strong. On the other hand, the correlation between FDI and inflation rate is not that strong as shown by the size of the correlation coefficient. In addition, most of the indicators for political risk and institutions quality are fairly strongly related to gdp, indicating that richer countries possess less political risk and have better institutions.

Table 1: Descriptive statistics

\begin{tabular}{|c|c|c|c|c|c|}
\hline Variables & Obs & Mean & Std. Dev. & Min & Max \\
\hline FDI & 150 & 2.023 & 3.949 & -8.757 & 46.488 \\
\hline GDP & 150 & 8.367 & 1.274 & 4.870 & 12.560 \\
\hline DO & 150 & 70.594 & 32.627 & 11 & 296 \\
\hline CORR & 150 & 2.435 & 1.101 & 0 & 6 \\
\hline ROL & 150 & 2.682 & 1.087 & 0 & 5 \\
\hline DEMO & 150 & 2.713 & 1.248 & 0 & 5.500 \\
\hline BURQAL & 150 & 1.333 & 0.940 & 0 & 4 \\
\hline EXCHRAT & 150 & 118.364 & 55.934 & 29 & 772 \\
\hline INFL & 150 & 85.746 & 1039.601 & -29 & 26762 \\
\hline NATRES & 150 & 0.333 & 0.472 & 0 & 1 \\
\hline INCONF & 150 & 7.247 & 2.559 & 0 & 12 \\
\hline EXCONF & 150 & 8.633 & 2.326 & 2 & 12 \\
\hline PROFINV & 150 & 5.834 & 2.187 & 0 & 11.5 \\
\hline STABGOV & 150 & 7.038 & 2.454 & 0.667 & 11.583 \\
\hline
\end{tabular}


Table 2: Correlation matrix of the variables included in model

\begin{tabular}{|c|c|c|c|c|c|c|c|c|c|c|c|c|c|c|c|}
\hline & FDI & $\begin{array}{l}\text { Market } \\
\text { size }\end{array}$ & growth & Exchrat & natres & Open & Infl & Rol & Corr & Stabgov & Profinv & Inconf & Exconf & Demo & Burgal \\
\hline FDI & 1.000 & & & & & & & & & & & & & & \\
\hline Market size & $0.174^{b}$ & 1.000 & & & & & & & & & & & & & \\
\hline growth & $0.483^{\mathrm{a}}$ & 0.101 & 1.000 & & & & & & & & & & & & \\
\hline Exchrat & $0.656^{\mathrm{a}}$ & $0.149^{c}$ & $0.401^{\mathrm{a}}$ & 1.000 & & & & & & & & & & & \\
\hline natres & $0.722^{\mathrm{a}}$ & $0.180^{b}$ & $0.329^{\mathrm{a}}$ & $0.658^{\mathrm{a}}$ & 1.000 & & & & & & & & & & \\
\hline Open & $0.775^{\mathrm{a}}$ & 0.092 & $0.447^{\mathrm{d}}$ & $0.731^{\mathrm{a}}$ & $0.680^{\mathrm{a}}$ & 1.000 & & & & & & & & & \\
\hline Infl & 0.093 & -0.009 & $(-0.136)^{c}$ & 0.021 & $0.152^{c}$ & 0.055 & 1.000 & & & & & & & & \\
\hline Rol & $0.779^{\mathrm{a}}$ & 0.131 & $0.511^{\mathrm{a}}$ & $0.810^{\mathrm{A}}$ & $0.623^{\mathrm{a}}$ & $0.833^{\mathrm{a}}$ & 0.032 & 1.0000 & & & & & & & \\
\hline Corr & $0.677^{\mathrm{a}}$ & $0.206^{b}$ & $0.437^{\mathrm{d}}$ & $0.808^{\mathrm{d}}$ & $0.589^{\mathrm{a}}$ & $0.775^{\mathrm{a}}$ & 0.001 & $0.8810^{\mathrm{a}}$ & 1.000 & & & & & & \\
\hline Stabgov & $0.800^{\mathrm{a}}$ & $0.195^{b}$ & $0.534^{\mathrm{A}}$ & $0.791^{\mathrm{d}}$ & $0.712^{\mathrm{a}}$ & $0.846^{\mathrm{a}}$ & 0.060 & $0.9057^{\mathrm{d}}$ & $0.825^{\mathrm{a}}$ & 1.000 & & & & & \\
\hline Profinv & $0.780^{a}$ & $0.241^{\mathrm{a}}$ & $0.531^{\mathrm{a}}$ & $0.804^{\mathrm{a}}$ & $0.687^{\mathrm{d}}$ & $0.820^{\mathrm{a}}$ & 0.029 & $0.9152^{\mathrm{d}}$ & $0.851^{\mathrm{a}}$ & $0.948^{\mathrm{a}}$ & 1.000 & & & & \\
\hline Inconf & $0.786^{\mathrm{a}}$ & $0.172^{b}$ & $0.502^{\mathrm{a}}$ & $0.822^{\mathrm{a}}$ & $0.693^{\mathrm{a}}$ & $0.843^{\mathrm{a}}$ & 0.051 & $0.9359^{\mathrm{a}}$ & $0.858^{\mathrm{a}}$ & $0.945^{\mathrm{d}}$ & $0.955^{\mathrm{a}}$ & 1.000 & & & \\
\hline Exconf & $0.778^{\mathrm{a}}$ & $0.197^{b}$ & $0.470^{\mathrm{d}}$ & $0.834^{d}$ & $0.737^{\mathrm{d}}$ & $0.846^{\mathrm{a}}$ & 0.093 & $0.9226^{\mathrm{a}}$ & $0.862^{\mathrm{a}}$ & $0.948^{\mathrm{a}}$ & $0.945^{\mathrm{a}}$ & $0.970^{\mathrm{a}}$ & 1.000 & & \\
\hline Demo & $0.750^{\mathrm{a}}$ & $0.271^{\mathrm{a}}$ & $0.493^{\mathrm{a}}$ & $0.786^{\mathrm{a}}$ & $0.661^{\mathrm{d}}$ & $0.777^{\mathrm{a}}$ & 0.055 & $0.9024^{\mathrm{a}}$ & $0.871^{\mathrm{a}}$ & $0.901^{\mathrm{a}}$ & $0.934^{\mathrm{d}}$ & $0.931^{\mathrm{a}}$ & $0.923^{\mathrm{a}}$ & 1.000 & \\
\hline Burqal & $0.664^{\mathrm{a}}$ & $0.277^{\mathrm{a}}$ & $0.362^{\mathrm{a}}$ & $0.778^{\mathrm{a}}$ & $0.643^{\mathrm{a}}$ & $0.758^{\mathrm{a}}$ & 0.061 & $0.8344^{\mathrm{a}}$ & $0.861^{\mathrm{a}}$ & $0.817^{\mathrm{a}}$ & $0.848^{9}$ & $0.849^{\mathrm{a}}$ & $0.849^{\mathrm{a}}$ & $0.859^{\mathrm{a}}$ & 1.000 \\
\hline
\end{tabular}

a; b; c denote significance levels at $1 \%, 5.0 \%$ and $10 \%$ respectively

A central issue before making the appropriate specification, often ignored by past researchers, is to test if the variables are stationary or not. Since the papers by Levin \& Lin (1992, 1993), this test has become popular. We thus carry out panel unit root tests on the dependent and independent variables. We follow the approach of Levin \& Lin (LL test) and Im, Pesaran, and Shin (IPS test) who developed a panel unit root test for the joint null hypothesis that every time series in the panel is non stationary. This approach is based on the average of individual series ADF test and has a standard normal distribution once adjusted in a particular manner. The results of these tests suggest that in every case we reject a unit root in favour of stationary at the 5 percent significance level.

Table 3: Results of Panel Unit Root Tests

\begin{tabular}{|c|c|c|c|c|c|c|c|c|c|c|}
\hline Variables & FDI & BURQAL & ROL & DEMO & CORR & DO & INV & CHAS & GOV & NATRES \\
\hline LL Test & -2.89 & -1.84 & -2.802 & -1.69 & -8.31 & -1.66 & -11.85 & -8.69 & -10.78 & -8.0569 \\
& $(0.001)$ & $(0.033)$ & $(0.000)$ & $(0.041)$ & $(0.000)$ & $(0.040)$ & $(0.000)$ & $(0.000)$ & $(0.000)$ & $(0.000)$ \\
\hline IPS Test & -2.035 & -9.77 & -1.85 & -1.35 & -9.54 & -1.96 & -1.34 & -9.62 & -13.84 & -6.370 \\
& $(0.02)$ & $(0.000)$ & $(0.030)$ & $(0.089)$ & $(0.000)$ & $(0.020)$ & $(0.09)$ & $(0.000)$ & $(0.000)$ & $(0.0000)$ \\
& & & & & & & & & & \\
\hline Variables & EXCHRAT & INFR & GDP & DEBT & INFL & EXCONF & INCONF & STABGOV & PROFINV & TXGDP \\
\hline LL Test & -2.69 & -3.492 & -6.10 & -2.56 & -5.86 & -3.19 & -2.26 & -1.87 & -2.21 & -5.35 \\
& $(0.003)$ & $(0.000)$ & $(0.000)$ & $(0.005)$ & $(0.000)$ & $(0.000)$ & $(0.011)$ & $(0.032)$ & $(0.012)$ & $(0.000)$ \\
\hline IPS Test & -2.78 & -3.15 & -11.02 & -3.23 & -6.78 & -3.50 & -1.98 & -0.38 & -1.34 & -8.05 \\
& $(0.003)$ & $(0.000)$ & $(0.050)$ & $(0.000)$ & $(0.000)$ & $(0.047)$ & $(0.020)$ & $(0.031)$ & $(0.090)$ & $(0.000)$ \\
& & & & & & & & & & \\
\end{tabular}

Note: P-values are in parentheses 


\section{Empirical Results}

To empirically assess the role played by institutions in determining FDI inflows, Models 2 and 3 are based on a random effect specification of the basic model. This specification is supported by a Hausman test, reported in table 4.1. The empirical investigation will first cover the impact of institutions on FDI for all samples, and then the role of institutions at countries characteristics (resource intensive countries and non-resource intensive countries) will be considered.

\subsection{The Results from Total Sample}

The results are based on a random-effects model, since the Hausman (1978) test suggests using a random-effects model instead of a fixed-effects model in most of cases. The key estimates in the tables are the coefficients on institutions and natural resources.

Column 1 of Table 4.1 reports the results of the benchmark Model without the institutions variable, Inst. All control variables have the expected sign. The results shows that FDI were attracted to countries with abundance natural resources, with growing markets, as the coefficient on GDP growth rate is positive and significant. This may indicate that market-related variables are important for FDI. However, the other market size indicator, the log of GDP per capita, appears insignificant; indicating that market size is not an important factor in explaining the variations of FDI within the considered sample. The results in column 1 also show that trade openness, as measured by trade-GDP ratio, and natural resources have a positive and significant impact on FDI, and those countries with higher trade-GDP ratio or resource-intensive countries attracted, ceteris paribus, more FDI. Furthermore, exchange rate and macroeconomic stability, as measured by the percentage change on consumer price index, are insignificantly related to FDI.

We then add the indicators for political risk and institutions one by one to the model to see whether they explain any variation to the control variables. The results are in column 2 to 8 of the Table 4.1. Our findings indicate that all indicators, except corruption control and quality of bureaucracy, are significant and positively correlated with FDI flows. These results indicate that institutions play significant roles in determining FDI inflows. This means that FDI is attracted to countries with high quality institutions that protect property rights. The results for government stability and democratic accountability of the government show that foreign investors are highly sensitive to changes in political stability and the framework in which governments operate. Fundamental democratic rights, like civil liberties and political rights do matter to multinationals operating in SSA countries, even when we control for other factors that affect FDI flows. These results are in line with the findings by Busse and Hefeker (2007), Busse (2004) and Jensen (2003), which all showed that basic democratic rights are positively correlated with FDI inflows, even if the specifications of their models differ.

Moreover, the relative importance of investment profile is hardly surprising, given that profinv contains key subcomponents, such as contract viability, expropriation of assets or the ability of multinationals to repatriate profits. Clearly, these subcomponents are exceptionally important for multinationals decisions on where to invest. In the same way, foreign investors seem to care about internal and external conflicts that affect the host country of their investment, as it increases economic and political instability. The threat of incidence of these conflicts, such as civil war, trade sanctions, cross-boarder conflicts or an all-out war, creates higher uncertainty. Thus, investors increase the risk premium of 
investment projects, which in turn reduces overall investment. In addition, such conflicts have a strong negative impact on a country's growth rate, thus making investment generally less attractive.

Table 4.1: Panel Data Estimations, 1984-2007 (5-years averages): All countries

\begin{tabular}{|c|c|c|c|c|c|c|c|c|c|}
\hline & Model $_{0}$ & Rol & Corr & Stabgov & Profinv & Inconf & Exconf & Demo & Burqal \\
\hline Size of market & 0.0000 & 0.0000 & 0.0000 & 0.0000 & 0.0000 & 0.0000 & 0.0000 & 0.0000 & 0.0000 \\
\hline Exchrat & -0.0066 & $-0.0404^{\mathrm{b}}$ & -0.0031 & -0.0116 & -0.0193 & -0.0319 & -0.0213 & -0.0206 & -0.0145 \\
\hline Growth & $0.7148^{\mathrm{c}}$ & 0.4444 & $0.7124^{c}$ & 0.3049 & 0.4709 & 0.3782 & $0.6148^{\mathrm{c}}$ & 0.5469 & $0.7375^{\mathrm{b}}$ \\
\hline Open & $0.2380^{\mathrm{a}}$ & $0.1209^{\mathrm{a}}$ & $0.2450^{\mathrm{a}}$ & $0.1090^{\mathrm{b}}$ & $0.1644^{\mathrm{a}}$ & $0.1294^{\mathrm{a}}$ & $0.1624^{\mathrm{a}}$ & $0.1857^{\mathrm{a}}$ & $0.2186^{\mathrm{a}}$ \\
\hline Infl & 0.0011 & 0.0006 & 0.0011 & 0.0016 & 0.0018 & 0.0008 & 0.0006 & 0.0006 & 0.0010 \\
\hline Natres & $0.2658^{\mathrm{a}}$ & $0.2224^{\mathrm{a}}$ & $0.2672^{\mathrm{a}}$ & $0.1301^{\mathrm{c}}$ & $0.1974^{\mathrm{a}}$ & $0.1876^{\mathrm{a}}$ & $0.2021^{\mathrm{a}}$ & $0.2320^{\mathrm{a}}$ & $0.2585^{\mathrm{a}}$ \\
\hline Inst & & $0.4672^{\mathrm{a}}$ & -0.3892 & $\begin{array}{c}2.3717^{\mathrm{a}} \\
-10.285\end{array}$ & $1.7734^{\mathrm{a}}$ & $1.7393^{\mathrm{a}}$ & $1.1497^{\mathrm{b}}$ & $2.4669^{\mathrm{b}}$ & 1.4260 \\
\hline Constant & $-9.1613^{\mathrm{a}}$ & $-6.9812^{b}$ & $-9.1362^{\mathrm{a}}$ & $4^{\mathrm{a}}$ & $-9.5509^{\mathrm{a}}$ & $-7.3058^{\mathrm{b}}$ & -9.4635 & $-8.5979^{a}$ & -8.5405 \\
\hline $\mathbf{R}^{2}$ & $\begin{array}{c}0.6884 \\
524.920\end{array}$ & $\begin{array}{c}0.7257 \\
632.490\end{array}$ & $\begin{array}{c}0.6860 \\
523.330\end{array}$ & $\begin{array}{c}0.7081 \\
666.160\end{array}$ & $\begin{array}{c}0.7115 \\
567.320\end{array}$ & $\begin{array}{c}0.7111 \\
596.020\end{array}$ & $\begin{array}{c}0.7016 \\
553.980\end{array}$ & $\begin{array}{c}0.7071 \\
549.540\end{array}$ & $\begin{array}{c}0.6894 \\
529.080\end{array}$ \\
\hline Wald test & 0 & 0 & 0 & 0 & 0 & 0 & 0 & 0 & 0 \\
\hline Prob $>$ Chi2 & 0.0000 & 0.0000 & 0.0000 & 0.0000 & 0.0000 & 0.0000 & 0.0000 & 0.0000 & 0.0000 \\
\hline $\begin{array}{l}\text { No countries } \\
\text { No } \\
\text { observations }\end{array}$ & 150 & 150 & 150 & 150 & 150 & 30 & 30 & 150 & 150 \\
\hline Hausman test & 4.1400 & 0.8700 & 5.9800 & 4.0500 & 0.9000 & 3.0800 & 2.1200 & 1.8900 & 3.1700 \\
\hline $\begin{array}{l}\text { Prob }>\text { Chi2 } \\
\text { Random } \\
\text { effects }\end{array}$ & 0.6574 & 0.9900 & 0.4252 & 0.7736 & 0.9833 & 0.8774 & 0.9528 & 0.9299 & 0.7872 \\
\hline Fixed effects & No & No & No & No & No & No & No & No & No \\
\hline
\end{tabular}

a; b; c denote significance levels at 1\%, 5.0\% and 10\%, respectively.

Several aspects of the results from different variants of Model can be highlighted: First, it seems that institutions have a positive and significant impact on FDI and that this impact is not sensitive to controlling variable changes. Second, as far as the country sample and time period covered are concerned, it seems that FDI is driven mainly by the liberty of the trade regime, natural resources and institutional quality, and to a lesser extent, by growth of market size, while market size indicators, exchange rate, and macroeconomic stability did not play a significant role in determining FDI inflows.

Given these results, it might be interesting, especially for policymakers, to explore the relative importance of institutions in attracting FDI inflows compared with other variables, particularly with policy related variables like inflation rate. This is particularly important as empirical literature provides little guidance on the relative contribution of institutional quality in attracting FDI.

In the first regression in Table 4.1., the interaction effect between institutions and natural resources is not included. The second regression (Table 4.2) shows, however, that excluding the interaction between resources and institutions is too restrictive an empirical model. When adding the interaction between institutions and natural resources, we get a 
significant result for this term, while results otherwise are qualitatively unchanged. In other words, rejecting the influence of institutions and natural resources on FDI flows in SSA based on the first regression would be premature. In fact, what the significance of the interaction effect tells us is that the effect of natural resources on FDI depends on the institutions of the host country. In fact, the analysis of the interaction between the indicators of institutions quality and natural resources show that impact of external conflict, democratic accountability and quality of bureaucracy on FDI flows depends on abundance of natural resources in host countries. On the other hand, when we control for corruption as an indicator, our result shows that the impact of natural resources on FDI flows depends on the quality of institutions in host countries. Moreover, interaction between natural resources and internal conflict, rule and law and government stability reveals any impact on the FDI flows in host countries.

These findings suggest some important implications: For countries with bad institutional quality, natural resources attract FDI in host countries. For countries with good institutions quality FDI is discouraged by natural resources. And the worse institutions in the host country, the more is FDI attracted by natural resources. Conversely, the effect of institutions also depends on the natural resources. The more there are natural resources, the more is FDI attracted by poor institutions. In sum, FDI is attracted to countries which combine large natural resources and poor institutions.

Table 4.2: Panel Data Interactions Estimations, 1984-2007 (5-years averages): All countries

\begin{tabular}{lcccccccc}
\hline \hline & Rol & Corr & Stabgov & Profinv & Inconf & Exconf & Demo & Burqal \\
\hline \hline Size of market & 0.0002 & 0.0000 & 0.0000 & 0.0000 & 0.0000 & 0.0000 & 0.0000 & 0.0000 \\
Exchrat & $-0.0345^{\mathrm{c}}$ & $-0.0524^{\mathrm{b}}$ & -0.0267 & $-0.0457^{\mathrm{c}}$ & $-0.0453^{\mathrm{c}}$ & $-0.0595^{\mathrm{b}}$ & $-0.0546^{\mathrm{b}}$ & $-0.0547^{\mathrm{b}}$ \\
Growth & 0.4571 & $0.8348^{\mathrm{b}}$ & 0.3633 & 0.5935 & 0.4513 & $0.7143^{\mathrm{b}}$ & $0.6871^{\mathrm{c}}$ & $0.7762^{\mathrm{b}}$ \\
Open & $0.1156^{\mathrm{b}}$ & $0.1276^{\mathrm{b}}$ & $0.1865^{\mathrm{a}}$ & $0.1217^{\mathrm{b}}$ & $0.1083^{\mathrm{b}}$ & $0.1112^{\mathrm{b}}$ & $0.1242^{\mathrm{b}}$ & $0.1314^{\mathrm{b}}$ \\
Infl & 0.0006 & 0.0007 & 0.0014 & 0.0013 & 0.0007 & 0.0005 & 0.0005 & 0.0007 \\
Natres & $0.2150^{\mathrm{a}}$ & 0.1137 & $0.2079^{\mathrm{a}}$ & $0.1568^{\mathrm{b}}$ & $0.1646^{\mathrm{b}}$ & $0.1475^{\mathrm{b}}$ & $0.1651^{\mathrm{b}}$ & $0.1731^{\mathrm{b}}$ \\
Inst & $4.4604^{\mathrm{a}}$ & $-3.8198^{\mathrm{a}}$ & $2.0566^{\mathrm{a}}$ & $0.9861^{\mathrm{a}}$ & $1.3777^{\mathrm{b}}$ & 0.1544 & -0.7733 & -1.1090 \\
Inst*Natres & 0.0011 & $0.0255^{\mathrm{a}}$ & 0.0019 & $-0.0073^{\mathrm{a}}$ & 0.0018 & $0.0046^{\mathrm{b}}$ & $0.0115^{\mathrm{b}}$ & $0.0228^{\mathrm{a}}$ \\
Constant & -5.5574 & $16.2931^{\mathrm{b}}$ & -4.5681 & 1.2726 & -1.4909 & 7.3976 & 5.0442 & 7.4475 \\
& & & & & & & & \\
\hline$R^{2}$ & 0.7252 & 0.6907 & 0.7081 & 0.7092 & 0.7098 & 0.7036 & 0.7074 & 0.6994 \\
Wald test & 631.1500 & 605.9600 & 668.9100 & 577.9300 & 598.6700 & 577.9200 & 571.5900 & 564.1700 \\
Prob>Chi2 & 0.0000 & 0.0000 & 0.0000 & 0.0000 & 0.0000 & 0.0000 & 0.0000 & 0.0000 \\
No countries & 30 & 30 & 30 & 30 & 30 & 30 & 30 & 30 \\
No observations & 150 & 150 & 150 & 150 & 150 & 150 & 150 & 150 \\
\hline \hline
\end{tabular}

a;b;c denotes significance levels at 1\%, 5.0\% and 10\%, respectively.

\subsection{The Results based on Host Countries Characteristics}

The motives of FDI vary greatly across the countries in which firms operate. For example, for resource intensive countries, the primary reason for foreign investors to choose the 
location is abundance of natural resources. Despite the obvious importance of studies of FDI determinants at the more disaggregate level; the evidence on endowment differences is rather scarce in the existing literature. To analyze the relative impact of endowment differences, we divide the sample into three groups, resource-intensive countries (including oil exporting countries), resource-poor countries and oil exporting countries.

The studies surveyed above use total sample data to explore the role played by institutions in determining the variations of FDI inflows. However, some papers argue that the impact of institutions on FDI may differ across countries characteristics. For example, As Asiedu (2002), our results show that institutional indicators such as control of corruption, government stability, internal, external conflicts, democracy and quality of bureaucracy are insignificantly related to FDI. These results should not be surprising, since a country like Angola and Nigeria which ranked first in attracting FDI in Sub Saharan Africa, are also highly instable countries. The reason for this is that FDI to Angola and Nigeria are driven mostly by the availability of fuel resources, and that the returns on these investments are high enough to cover the risk of political instability. We conclude that most of indicators of political risk are less relevant for resource intensive countries, particularly in the oil exporting countries.

The coefficient of corruption has to be interpreted more carefully. Corruption is indexed such that the higher value refers to cleaner administration. Accordingly, a negative sign indicates that less corruption has positive impact on the economic growth. Both equation 2 and equation 3 indicate that less corruption in the host country would increase FDI. Although economic theory is ambiguous on the ultimate effects of corruption on FDI, it does propose several different mechanisms that can discourage FDI, including corrupt institutions acting as a tax on investment and heightened insecurity and uncertainty (see, for instance, Hakkala, Norback and Svaleryd 2005 and Wei 2000).

Our paper provides evidence comparing the effects of institutions on FDI with the effects of non-policy variables like the availability of natural resources. In general case, we conclude that countries that are small or lack natural resources can attract FDI by improving their institutions. More importantly, given the growing interest of many countries in attracting FDI inflows, policymakers may be interested more in knowing the relative importance of institutions compared with other policy tools they have rather than non-policy variables. This can help them to build their priorities for attracting FDI. 
Table 5.1: Panel Data Estimations, 1984-2007 (5-year averages): Resource intensive countries

\begin{tabular}{|c|c|c|c|c|c|c|c|c|c|}
\hline & & & & Stabgo & & & & & \\
\hline & Model $_{0}$ & Rol & Corr & $\mathbf{v}$ & Profinv & Inconf & Exconf & Demo & Burqal \\
\hline Size of market & -0.0001 & 0.0000 & 0.0001 & 0.0000 & $0.0004^{\mathrm{b}}$ & 0.0001 & 0.0001 & -0.0002 & -0.0001 \\
\hline Exchrat & -0.0519 & -0.0112 & -0.0474 & -0.0164 & -0.0513 & -0.0487 & -0.0553 & -0.0515 & -0.0437 \\
\hline Growth & 1.3611 & $0.2993^{\mathrm{a}}$ & $1.4055^{\mathrm{a}}$ & $1.3706^{\mathrm{b}}$ & $1.3091^{\mathrm{b}}$ & $1.0086^{\mathrm{a}}$ & $1.4033^{\mathrm{b}}$ & 1.0385 & $1.4878^{\mathrm{c}}$ \\
\hline Open & $0.2492^{c}$ & $0.3656^{\mathrm{b}}$ & $\begin{array}{l}0.3343^{a} \\
-0.0124\end{array}$ & $0.4219^{\mathrm{b}}$ & $\begin{array}{l}0.4324^{\mathrm{b}} \\
-0.0329\end{array}$ & $\begin{array}{l}0.3719^{a} \\
-0.0316\end{array}$ & $\begin{array}{l}0.4811^{b} \\
-0.0238\end{array}$ & $\begin{array}{l}0.4295^{b} \\
-0.0224\end{array}$ & $\begin{array}{l}0.4300^{b} \\
-0.0331\end{array}$ \\
\hline Infl & 0.0119 & $-0.0219^{a}$ & $\underset{\mathrm{a}}{-0.0124}$ & $-0.0334^{\mathrm{a}}$ & $\underset{b}{-0.03<9}$ & $\underset{\mathrm{a}}{-0.0310}$ & $\underset{b}{-0.0230}$ & $\begin{array}{c}-0.0<24 \\
b\end{array}$ & -0.0301 \\
\hline Natres & $0.3761^{\mathrm{a}}$ & $0.3389^{b}$ & $0.3635^{\mathrm{b}}$ & $0.2371^{\mathrm{b}}$ & $0.2592^{\mathrm{b}}$ & $0.2349^{\mathrm{a}}$ & $0.2222^{\mathrm{a}}$ & $0.1329^{c}$ & $0.2470^{\mathrm{b}}$ \\
\hline Inst & & $\begin{array}{c}1.4740^{\mathrm{a}} \\
-46.7312\end{array}$ & -1.2910 & 2.6324 & $0.8754^{\mathrm{a}}$ & 2.6192 & -1.3670 & 5.3475 & -3.6319 \\
\hline Constant & 7.2954 & c & 11.4004 & -4.7778 & 4.4742 & -2.8394 & 14.2222 & -9.1562 & 14.0153 \\
\hline $\mathbf{R}^{2}$ & $\begin{array}{l}0.2061 \\
10.990\end{array}$ & 0.4016 & 0.2337 & 0.3230 & 0.3095 & 0.2582 & 0.2976 & 0.2500 & 0.3974 \\
\hline Wald test & 0 & 23.9100 & 10.9300 & 14.8700 & 19.9400 & 12.9900 & 19.4600 & 13.2000 & 12.2900 \\
\hline Prob $>$ Chi2 & 0.0888 & 0.0012 & 0.0518 & 0.0317 & 0.0017 & 0.0393 & 0.0019 & 0.0373 & 0.0413 \\
\hline $\begin{array}{l}\text { No countries } \\
\text { No }\end{array}$ & 10 & 10 & 10 & 10 & 10 & 10 & 10 & 10 & 10 \\
\hline observations & 50 & 50 & 50 & 50 & 50 & 50 & 50 & 50 & 50 \\
\hline Hausman test & 4.1400 & 1.0500 & 1.1400 & 0.4800 & 0.3800 & 1.4600 & 0.1800 & 0.7000 & 13.9000 \\
\hline Prob $>$ Chi2 & 0.6574 & 0.9835 & 0.9799 & 0.9995 & 0.9990 & 0.9622 & 0.9999 & 0.9944 & 0.0308 \\
\hline Random effects & Yes & Yes & Yes & Yes & Yes & Yes & Yes & Yes & No \\
\hline Fixed effects & No & No & No & No & No & No & No & No & Yes \\
\hline
\end{tabular}

a;b;c denotes significance levels at 1\%, 5.0\% and 10\%, respectively. 
Table 5.2: Panel Data Estimations, 1984-2007 (5-year averages): Non-resource intensive countries

\begin{tabular}{|c|c|c|c|c|c|c|c|c|c|}
\hline & Model $_{0}$ & Rol & Corr & $\begin{array}{c}\begin{array}{c}\text { Stabgo } \\
\mathbf{v}\end{array} \\
\end{array}$ & $\begin{array}{c}\begin{array}{c}\text { Profin } \\
\mathbf{v}\end{array} \\
\end{array}$ & Inconf & Exconf & Demo & Burqal \\
\hline $\begin{array}{l}\text { Size of } \\
\text { market }\end{array}$ & 0.0001 & $\begin{array}{r}0.0001 \\
-0.0384\end{array}$ & 0.0000 & 0.0001 & 0.0000 & $\begin{array}{r}0.0001 \\
-0.0340\end{array}$ & 0.0001 & 0.0001 & 0.0001 \\
\hline Exchrat & -0.0262 & & -0.0122 & -0.0133 & -0.0216 & & -0.0268 & -0.0277 & -0.0316 \\
\hline Growth & 0.129 & -0.1236 & 0.2196 & -0.2784 & -0.2841 & -0.2921 & -0.0362 & -0.0694 & 0.1493 \\
\hline Open & $0.2266^{\mathrm{a}}$ & $0.1627^{\mathrm{a}}$ & $0.2516^{\mathrm{a}}$ & $0.1486^{\mathrm{a}}$ & $0.1644^{\mathrm{a}}$ & $0.1490^{\mathrm{a}}$ & $0.1391^{\mathrm{a}}$ & $0.1914^{\mathrm{a}}$ & $0.2082^{\mathrm{a}}$ \\
\hline Infl & -0.0018 & -0.0016 & -0.0018 & -0.0005 & -0.0006 & -0.0014 & -0.0016 & -0.0020 & -0.0019 \\
\hline Natres & $0.3646^{\mathrm{a}}$ & $\begin{array}{l}0.2383^{\mathrm{a}} \\
-1.6323\end{array}$ & $0.3727^{\mathrm{a}}$ & $0.1506^{\mathrm{c}}$ & $0.1924^{\mathrm{b}}$ & $0.1904^{b}$ & $0.1933^{\mathrm{b}}$ & $0.3145^{\mathrm{a}}$ & $0.3485^{\mathrm{a}}$ \\
\hline Inst & $3.6772^{\mathrm{a}}$ & $\begin{array}{r}c \\
-7.0037\end{array}$ & $1.9840^{\mathrm{a}}$ & $\begin{array}{r}2.0973^{\mathrm{a}} \\
-11.145\end{array}$ & $\begin{array}{l}1.7110^{\mathrm{a}} \\
-9.6264\end{array}$ & $\begin{array}{l}1.5638^{\mathrm{a}} \\
-7.5522\end{array}$ & $\begin{array}{l}1.7474^{\mathrm{b}} \\
-9.8007\end{array}$ & 1.3812 & 1.3812 \\
\hline Constant & -5.508 & c & -5.2672 & $2^{\mathrm{a}}$ & 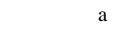 & $\mathrm{b}$ & b & -6.3092 & -5.2433 \\
\hline $\mathbf{R}^{2}$ & 0.8028 & 0.8441 & 0.7968 & 0.8393 & 0.8460 & 0.8482 & 0.8305 & 0.8160 & 0.8059 \\
\hline Wald test & $\begin{array}{r}1195.6 \\
400\end{array}$ & $\begin{array}{r}1463.7 \\
800\end{array}$ & $\begin{array}{r}1229.6 \\
500\end{array}$ & $\begin{array}{r}1613.4 \\
200\end{array}$ & $\begin{array}{r}1422.3 \\
900\end{array}$ & $\begin{array}{r}1425.6 \\
800\end{array}$ & $\begin{array}{r}1432.7 \\
100\end{array}$ & $\begin{array}{r}1223.4 \\
300\end{array}$ & $\begin{array}{c}1205.6 \\
900\end{array}$ \\
\hline $\begin{array}{l}\text { Prob>Chi2 } \\
\text { No }\end{array}$ & 0.0000 & 0.0000 & 0.0000 & 0.0000 & 0.0000 & 0.0000 & 0.0000 & 0.0000 & 0.0000 \\
\hline $\begin{array}{l}\text { countries } \\
\text { No } \\
\text { observation }\end{array}$ & 20 & 20 & 20 & 20 & 20 & 20 & 20 & 20 & 20 \\
\hline $\mathbf{s}$ & 100 & 100 & 100 & 100 & 100 & 100 & 100 & 100 & 100 \\
\hline $\begin{array}{l}\text { Hausman } \\
\text { test }\end{array}$ & 1.7300 & 1.1000 & 2.6900 & 0.5400 & 1.4500 & 3.4400 & 1.3300 & 2.4100 & 1.6800 \\
\hline $\begin{array}{l}\text { Prob }>\text { Chi2 } \\
\text { Random }\end{array}$ & 0.9425 & 0.9816 & 0.8465 & 0.9993 & 0.9841 & 0.8416 & 0.9875 & 0.8780 & 0.9466 \\
\hline $\begin{array}{l}\text { effects } \\
\text { Fixed }\end{array}$ & Yes & Yes & Yes & Yes & Yes & Yes & Yes & Yes & Yes \\
\hline effects & No & No & No & No & No & No & No & No & No \\
\hline
\end{tabular}

a;b;c denotes significance levels at 1\%, 5.0\% and 10\%, respectively.

The results of this paper show that institutions and natural resources have an interactive effect on foreign direct investment. The worse the institutional environment of a host country, the more is FDI attracted by the country's natural resources. These results add significantly to our understanding of FDI, since previous studies have not included these types of interaction effects, and therefore fail to capture an important relation between resource-richness and institutions. In fact, what the significance of the interaction effect tells us is that the effect of natural resources on FDI depends on the institutions of the host country. For countries with bad institutions, natural resources attract foreign investment. For countries with good institutions foreign investment is discouraged by natural resources. And the worse institutions in the host country, the more is foreign investment attracted by natural resources. Conversely, the effect of institutions also depends on the natural resources. The more there are natural resources, the more is FDI attracted by poor institutions. In sum, FDI is attracted to countries which combine large natural resources and poor institutions. 
From the perspective of policymakers in SSA countries, what are the chief implications of our findings? In a nutshell, poor nations can increase their FDI inflows by taking steps to (a) improve institutional quality (increase the level of Law and order and democracy, curb the level of corruption and external conflict etc...); (b) improve the level of openness of trade and exchange rate policy; and then (c) strongly encourage growth. However, rich nations can increase their FDI inflows by winning steps to (a) get better macroeconomic stability policy and find a way to manage natural resources; (b) promote foreign trade; and then (c) improve economic growth.

Table 6.1: Panel Data Interactions Estimations, 1984-2007 (5-year averages): Resource intensive countries

\begin{tabular}{|c|c|c|c|c|c|c|c|c|}
\hline & & & 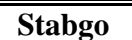 & & & & & \\
\hline & Rol & Corr & $\mathbf{v}$ & Profinv & Inconf & Exconf & Demo & Burqal \\
\hline Size of market & -0.0001 & $0.0018^{\mathrm{a}}$ & $0.0011^{\mathrm{a}}$ & 0.0000 & 0.0000 & -0.0002 & 0.0000 & -0.0001 \\
\hline Exchrat & -0.0311 & -0.0433 & -0.0053 & -0.0470 & -0.0423 & -0.0743 & -0.0478 & -0.0505 \\
\hline Growth & $0.8266^{\mathrm{b}}$ & $0.9570^{\mathrm{b}}$ & $0.8964^{\mathrm{b}}$ & $1.7141^{\mathrm{c}}$ & $1.6658^{\mathrm{c}}$ & $0.9454^{\mathrm{b}}$ & $1.6455^{\mathrm{c}}$ & 1.0491 \\
\hline Open & $0.4616^{\mathrm{a}}$ & $0.4831^{\mathrm{a}}$ & $0.4057^{\mathrm{b}}$ & $0.4262^{\mathrm{a}}$ & $\begin{array}{l}0.3944^{b} \\
-0.0213\end{array}$ & $\begin{array}{l}0.4732^{b} \\
-0.0370\end{array}$ & $0.4548^{\mathrm{a}}$ & $\begin{array}{l}0.4413^{\mathrm{a}} \\
-0.0246\end{array}$ \\
\hline Infl & $-0.0243^{b}$ & $-0.0244^{b}$ & $-0.0225^{\mathrm{b}}$ & $-0.0199^{c}$ & & a & $-0.0226^{\mathrm{b}}$ & \\
\hline Natres & $0.7879^{\mathrm{b}}$ & $0.9368^{\mathrm{a}}$ & $0.4004^{\mathrm{a}}$ & $0.5926^{\mathrm{b}}$ & $0.4526^{\mathrm{b}}$ & $0.2420^{\mathrm{a}}$ & $0.4020^{\mathrm{b}}$ & $0.6056^{\mathrm{a}}$ \\
\hline Inst & $2.3240^{\mathrm{a}}$ & $1.5258^{\mathrm{c}}$ & 1.0592 & $0.9465^{\mathrm{b}}$ & 2.1751 & -4.5978 & 0.8760 & 0.7703 \\
\hline Inst*Natres & $\begin{array}{l}-0.1378 \\
-73.500\end{array}$ & $\begin{array}{l}-0.3005^{b} \\
-35.157\end{array}$ & -0.0739 & $\begin{array}{l}-0.0688 \\
-15.410\end{array}$ & -0.0348 & 0.0729 & $\begin{array}{l}-0.0786 \\
-12.701\end{array}$ & $-0.2859^{a}$ \\
\hline Constant & 5 & 6 & 24.5327 & 5 & -9.4058 & 46.1511 & 0 & -4.7676 \\
\hline $\mathbf{R}^{2}$ & 0.4371 & 0.3449 & 0.4061 & 0.3131 & 0.2922 & 0.2607 & 0.2885 & 0.4167 \\
\hline Wald test & 27.4600 & 18.6200 & 20.4300 & 13.0600 & 12.5300 & 13.7000 & 14.3700 & 21.3000 \\
\hline Prob $>$ Chi2 & 0.0006 & 0.0070 & 0.0058 & 0.0599 & 0.0691 & 0.0590 & 0.0426 & 0.0044 \\
\hline $\begin{array}{l}\text { No countries } \\
\text { No }\end{array}$ & 10 & 10 & 10 & 10 & 10 & 10 & 10 & 10 \\
\hline observations & 50 & 50 & 50 & 50 & 50 & 50 & 50 & 50 \\
\hline
\end{tabular}

a;b;c denotes significance levels at 1\%, 5.0\% and 10\%, respectively. 
Table 6.2: Panel Data Interactions Estimations, 1984-2007 (5-year averages): Non-resource intensive countries

\begin{tabular}{|c|c|c|c|c|c|c|c|c|}
\hline & Rol & Corr & Stabgov & Profinv & Inconf & Exconf & Demo & Burqal \\
\hline Size & & $=0.000$ & & & & & & 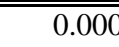 \\
\hline market & $\begin{array}{c}0.0001 \\
-0.073\end{array}$ & 0 & 0.0001 & 0.0000 & $\begin{array}{r}0.0001 \\
-0.0669\end{array}$ & 0.0001 & 0.0001 & 1 \\
\hline Exchrat & $5^{\mathrm{a}}$ & $-0.0776^{\mathrm{a}}$ & $-0.0520^{\mathrm{b}}$ & $-0.0629^{b}$ & a & $-0.0713^{\mathrm{a}}$ & $-0.0854^{\mathrm{a}}$ & $-0.0928^{\mathrm{a}}$ \\
\hline Growth & $\begin{array}{l}-0.061 \\
0.1081\end{array}$ & 0.3032 & -0.2048 & -0.1543 & -0.1884 & -0.0168 & 0.0564 & 0.0433 \\
\hline Open & $\begin{array}{c}\mathrm{a} \\
-0.001\end{array}$ & $0.1177^{\mathrm{a}}$ & $0.0999^{\mathrm{b}}$ & $0.1133^{\mathrm{a}}$ & $0.1050^{\mathrm{b}}$ & $0.0922^{\mathrm{b}}$ & $0.1074^{\mathrm{b}}$ & $0.1059^{b}$ \\
\hline Infl & 2 & -0.0011 & -0.0004 & -0.0006 & -0.0011 & -0.0013 & -0.0011 & -0.0001 \\
\hline Natres & $\begin{array}{l}0.1229 \\
1.9833\end{array}$ & -0.0104 & 0.0548 & 0.0932 & 0.0942 & 0.0806 & 0.0986 & 0.0965 \\
\hline Inst & $\mathrm{c}$ & $\begin{array}{l}-5.0025^{\mathrm{a}} \\
0.036\end{array}$ & $1.3497^{\mathrm{a}}$ & $1.0906^{\mathrm{c}}$ & $1.0436^{\mathrm{b}}$ & 0.7048 & -0.2807 & $\begin{array}{r}-2.5276^{c} \\
0.037\end{array}$ \\
\hline Inst*Natres & $0.0119^{\mathrm{b}}$ & $4^{\mathrm{a}}$ & $0.0047^{b}$ & $0.0063^{\mathrm{b}}$ & $0.0041^{\mathrm{b}}$ & $0.0049^{\mathrm{a}}$ & $\begin{array}{c}0.0195^{\mathrm{a}} \\
13.1542\end{array}$ & $9^{\mathrm{a}}$ \\
\hline Constant & 6.1128 & $23.9452^{\mathrm{a}}$ & 1.4917 & 4.5032 & 4.3858 & 6.4795 & & $16.6601^{\mathrm{a}}$ \\
\hline $\begin{array}{l}R^{2} \\
\text { Wald } \\
\text { test } \\
\text { Prob }>C\end{array}$ & $\begin{array}{c}0.8435 \\
1578.4 \\
700\end{array}$ & $\begin{array}{c}0.8154 \\
2152.58 \\
00\end{array}$ & $\begin{array}{c}0.8408 \\
1727.24 \\
00\end{array}$ & $\begin{array}{c}0.8432 \\
1522.03 \\
00\end{array}$ & $\begin{array}{c}0.8460 \\
1515.08 \\
00\end{array}$ & $\begin{array}{c}0.8339 \\
1570.07 \\
00\end{array}$ & $\begin{array}{c}0.8260 \\
1487.25 \\
00\end{array}$ & $\begin{array}{c}0.8232 \\
1545.43 \\
00\end{array}$ \\
\hline hi2 & 0.0000 & 0.0000 & 0.0000 & 0.0000 & 0.0000 & 0.0000 & 0.0000 & 0.0000 \\
\hline $\begin{array}{l}\text { No countries } \\
\text { No } \\
\text { observations }\end{array}$ & 20 & 100 & 20 & 20 & 20 & 20 & 20 & 20 \\
\hline
\end{tabular}

a;b;c denotes significance levels at 1\%, 5.0\% and 10\%, respectively.

\section{Conclusion}

Foreign direct investments are the most desirable form of capital inflows to emerging and developing countries because they are less susceptible to crises and sudden stops. The goal of this paper was to explore in detail the role of quality institutions in host countries as determinants of foreign direct investment and whether the role of quality of institutions varies according to certain characteristics of countries (resource intensive countries and non-resource intensive countries). As we have pointed out, our main contribution is not to find new and provocative policy recommendation but to distinguish several alternative hypotheses about the relative influence of such factors as natural resources availability and quality of institutions more broadly in those countries. This paper has also attempted to make a contribution to the empirical literature on the relationship between FDI and the institutional quality using a panel data model covering 30 SSA countries over the period 1984 to 2007.

These results show that institutional quality in host countries is one of the most important determinants of FDI inflows. In particular, institutional quality in host countries appeared more important for foreign investors than many other characteristics of host countries, 
such as market size, growing of market size, openness, etc. Another important finding in this paper is that the rule and law (security of property rights) appeared to be the most important institutions attribute for foreign investors, i.e. property rights protection is more important than democracy, corruption, political stability, and investment profile. However, the results of regression also showed that the importance of institutions varies across countries potentiality whether country is resource intensive countries or non-resource intensive countries. In particular, it appears that institutions do play a significant role in determining the flows of FDI in countries that are not resource-intensive. Moreover, the results show that there is tentative evidence that resource-intensive countries are less sensitive to institutional quality than natural resource-poor countries are.

These findings suggest some important implications: first, they enhance our understanding of the contribution of FDI to economic growth, and show that the impact of FDI on growth is not limited to its role in improving technology, but rather goes further beyond that, and includes a positive influence on institutional quality. Second, these findings indicate that the favorable development effects of FDI are in actuality greater than what is usually thought, and therefore these additional benefits must be taken into account when evaluating the merits of the programs aiming to attract FDI.

Considering the interactions impact, our results show that the worse institutions in the host country, the more is foreign investment attracted by natural resources. Conversely, the effect of institutions also depends on the natural resources. In sum, FDI is attracted to countries which combine large natural resources and poor institutions.

For future work, we can explore the role of other institutional determinants developed by La Porta et al. (1999) and compare the impacts of both types of indicators on FDI. The question of threshold could be analyzed by looking for different levels of institutional quality that could affect the behaviour of foreign investors. Furthermore, additional work could be done to take account of possible structural breaks for both variables.

\section{References}

[1] Acemoglu, D., J. A. Robinson and S. Johnson (2001), The Colonial Origins of Comparative Development: An Empirical Investigation, American Economic Review, 91, (2001), 1369-1401.

[2] Acemoglu D., J. A. Robinson, Y. Thaicharoen and S. Johnson, Institutional Causes, Macroeconomic Symptoms: Volatility, crises and Growth, Journal of Monetary Economics, V50, (2003) 49-123.

[3] Acemoglu, D., \& Johnson, S. (2005), Unbundling Institutions, Journal of Political Economy, (2003), 949-995.

[4] Agiomirgianakis, G., Astenou, D. and Papathoma, K., The Determinants of Foreign Direct Investment: A panel data study for the OECD countries City University London. Department of Economics, 03/06 (2003).

[5] Alfaro, L. et al. (2005)., «Capital Flows in a Globalized World: The Role of Policies and Institutions.», Working Paper for the NBER Conference on International Capital Flows.

[6] Alladina, F. L. B. S. N., and S. Lederer, Foreign Direct Investment in Sub-Saharan Africa: Motivating Factors and Policy Issues, Journal of African Business, 10, (2009) $141-162$. 
[7] Alsan M., Bloom D. E., D. Canning, The Effect of Population Health on Foreign Direct Investment, NBER Working Paper 10596 (2004).

[8] Asiedu, E., Foreign Direct Investment to Africa: The Role of Government Policy, Governance and Political Instability, Department of Economics, University of Kansas (2003).

[9] Asiedu, E., Foreign Direct Investment in Africa: The Role of Natural Resources, Market Size, Government Policy, Institution and Political Instability, WIDER Research Paper No 2005/24 (2005).

[10] Asiedu, E. and A. Villamil, Discount Factors and Thresholds: Foreign Investment when Enforcement is Imperfect, Macroeconomic Dynamics, 4(1), (2000) 1-21.

[11] Atkinson, G., \& Hamilton, K.,. Savings,Ggrowth and the Resource Curse Hypothesis, World Development 31, (2003) 1793-1807.

[12] Banga, R., Impact of Government Policies and Investment Agreements of FDI Inflows, Indian Council for Research of International Economic Relations Working Paper 116 (2003).

[13] Bank, W., Patterns of Africa-Asia Trade and Investment, Potential for Ownership and Partnership Volume 1 (2004), Octobre.

[14] Batana Y. M., Analysis of the Determinants of Foreign Direct Investment Flows in WAEMU Countries, African Journal of Economic Policy, 11(2) (2004).

[15] Bénassy-Quéré, A.; M., Coupet, and T., Mayer, Institutional Determinants of Foreign Direct Investment, Journal compilation (C) Blackwell Publishing Ltd. 2007(2007).

[16] Blomberg, Brock S., Gregory D. Hess and Akila Weerapana, Economic Conditions and Terrorism, European Journal of Political Economy, 20(2), (2004), 463-47.

[17] Blomström M. et A. Kokko, Regional Integration and Foreign Direct Investment: A Conceptual Framework and Three Cases, World Bank, Policy Research Working Paper No 1750, (1997) April.

[18] Blomstrom M., Lipsey, R.E and Zejan, M.,, Is Fixed Investment the Key to Economic Growth?, Quarterly Journal of Economics, 111, (1996) 269-276.

[19] Borensztein, J., J. De Gregorio and J-W. Lee, How Does Foreign Direct Investment Affect Economic Growth?, Journal of International Economics, 45 (1998), 115-135.

[20] Buckley, P. J., Clegg, L. J., Cross, A. R., Liu, X., Voss, H., and Zheng, P, The Determinants of Chinese Outward Foreign Direct Investment, Journal of International Business Studies, 38 (2007), 499-518

[21] Busse, M. et C. Hefeker, Political Risk, Institutions and Foreign Direct Investment, HWWA Discussion Paper, No 315 (2005).

[22] Campos, N. F. and Y. Kinoshita, Estimating the Determinants of Foreign Direct Investment Inflows: How important are Sampling and Omitted Variable Biases? ", BOFIT Discussion Papers No 10 (2004).

[23] Chan, K. K. and E. R. Gemayel, Macroeconomic Instability and the Patterns of FDI in the MENA Region, Preliminary Draft, IMF Working Paper (2003).

[24] Cheng, L. K. and Ma, Z, China's Outward Foreign Direct Investment, Paper presented at the Indian Statistical Institute, 12 December 2008, http://www.isid.ac.in/ pu/seminar/12_12_2008_Paper.doc

[25] Cheung, Y. W. and Qian, X. W., The empirics of China's outward direct investment Munich: CESifo GmbH (2008).

[26] Collier, P., \& Hoeffler, A.. Resource Rents, Governance, and Conflict, Journal of Conflict Resolution, 49, (2005) 625-633. 
[27] Dahl, J., Incentives for Foreign Direct Investment: The Case of SADC in the 1990s, NEPRU Working Paper No. 81 (2002).

[28] Daude, C. and E. Stein., The Quality of Institutions and Foreign Direct Investment, Economics \& Politics, 69(3) (2007).

[29] Dunning, J. H., Trade, Location of Economic Activity and the MNE: A Search for an Eclectic Approach in Ohlin, B., Hesselborn, P. O., and Wijkman, P. M. (eds.), The International Location of Economic Activity, London: Macmillan (1977) 395-418.

[30] Dunning, J. H., Multinational Enterprises and the Global Economy, Wokingham, England: Addison-Wesley (1993).

[31] Dunning, J. H., A Rose By Any Other Name? FDI Theory in Retrospect and Prospect, Mimeo, University of Reading and Rutgers University (1999).

[32]] Easterly, W. and R. Levine, Tropics, Germs and Corps: How Endowments Influence Economic Development», NBER Working Paper No. 9106 (2002).

[33] Easterly, W. and R. Levine, Africa's Growth Tragedy: Policies and Ethnic Divisions, Quarterly Journal of Economics, 112 (1997) 1203-50.

[34] Edison, H., How Strong Are the Links between Institutional Quality and Economic Performance?, Finance \& Development, 40(2) (2003).

[35] Edwards S. (1990), Capital Flows, Foreign Direct Investment, and Debt-Equity Swaps in Developing Countries, NBER Working Paper No 3497, Cambridge (2003), October.

[36] Fiodendji, K.,. Quality of Institutions and Foreign Direct Investment (FDI) in Sub-Saharan Africa: Dynamic Approach, Final Report, AERC (2009)

[37] Glaeser E. L., R. La Porta, F. Lopez-de-Silanes and A. Shleifer, Do Institutions Cause Growth? Journal of Economic Growth, 9(3) (2004).

[38] Globerman, S. and D. Shapiro, Infrastructure, politique nationale et investissement étranger direc, Programme des [39] Publications de Recherche d'Industrie Canada, Document de travail no 37 (2002), December.

[39] Hall R., and C. Jones, Why Do Some Countries Produce so more Output per Worker than Others?, Quarterly Journal of Economics, 114 (1), (1999) 83-116.

[40] Kaufmann, D., Kraay, A. and Mastruzzi, M., Governance Matters VII: Aggregate and Individual Governance Indicators 1996-2007, World Bank Policy Research Working Paper 4654 (2008), Washington D.C.

[41] Kolstad, I., and A. Wiig. What Determines Chinese Outward FDI? CMI Discussion paper (2009).

[42] Kostevc, Č, Redek, T. and Sušjan, A. Foreign Direct Investment and Institutional Environment in Transition Economies. Transition Studies Review, 14(1), (2007). 40-54.

[43] Mishra, A. and K., Daly, Effect of Quality of institutions on Outward Foreign Direct Investment, The Journal of International Trade \& Economic Development An International and Comparative Review (2000).

[44] Mody, Ashoka and Krishna Srinivasan, Japanese and United States Firms as Foreign Investors: Do They March to the Same Tune? Washington, DC: World Bank, (1996) mimeo.

[45] Morisset J., Foreign Direct Investment in Africa: Policies Also Matter, World Bank Policy Research Working Paper No 2481 (2000), November.

[46] Nsouli, S. M., Capacity Building in Africa: The Role of International Financial Institutions, Finance \& Development, 37(4) (2000). 
[47] Papyrakis, E., and Gerlagh, R., The Resource Curse Hypothesis and its Transmission Channels, Journal of Comparative Economics, 32 (2004), 181-193.

[48] Pigato M., Foreign Direct Investment in Africa: Old Tales and New Evidence, The World Bank, (2000) January.

[49] Proksch, M., Asian-African Trade and Investment Cooperation,” Asia-Pacific Trade and Investment Review, 4, (2008),141-157.

[50] PRS Group (2005a), About ICRG: The Political Risk Rating, Internet Posting: http://www.icrgonline.com/page.aspx?page=icrgmethods.

[51] PRS Group (2005b). International Country Risk Guide: Political Risk (Table 3b), Internet Posting: http://www.icrgonline.com/default.aspx.

[52] Rodrik, D.,TFPG Controversies, Institutions, and Economic Performance in East Asia, NBER Working Paper No 5914 (1997).

[53] Rodrik, D. and al., Institutions Rule: The Primacy of Institutions over Geography and Integration in Economic Development, NBER Working Paper 9305 (2002).

[54] Rugman A. M. New Theories of the Multinational Enterprise: An Assessment of Internalization Theory, Bulletin of Economic Research 38(2) (1986), 101-118.

[55] Sachs, J. D., Institutions Don't Rule: Direct Effects of Geography on Per Capita Income, NBER Working Paper 9490 (2003).

[56] Sachs and Warner, Natural Resource Abundance and Economic Growth, NBER Working Paper (1995).

[57] Sader F., Privatizing Public Enterprises and Foreign Investment in Developing Countries, 1988-93, IFC and World Bank Occasional Paper 5, (1995) Washington, D.C.

[58] Sala-i-Martin, X., \& Subramanian, A., Addressing the Natural Resource Ccurse: An Illustration from Nigeria, NBER Working Paper 9804 (2003).

[59] Sánchez-Robles, Blanca and Bengoa-Calvo, Marta, Foreign Direct Investment, Economic Freedom and Growth: New Evidence from Latin-America, Universidad de Cantabria, Economics Working Paper No. 4/03 (2002).

[60] Singh H. et K. W. Jun, Some New Evidence on Determinants of Foreign Direct Investment in Developing Countries, World Bank Policy Research Working Paper No 1531, (1995) November.

[61] Stasavage, D., Private Investment and Political Institutions, Economics and Politics 14, (2002,) 41-63.

[62] Statistical Bulletin of China’s Outward Foreign Direct Investment (2006)

[63] Stein, E. and Daude, C., Institutions, Integration and the Location of FDI, New Horizons of Foreign Direct Investment, OECD Global Forum on International Investment, Paris: OECD (2002).

[64] Stijns, J.-P. C., Natural Resource Abundance and Economic Growth Revisited, Resources Policy, 30 (2005), 107-130.

[65] Stijns, J.-P.., Natural Resource Abundance and Human Capital Accumulation,. World Development 34 (2006), 1060-1083.

[66] The World Bank, World Development Indicators 2003 to 2008. Washington, DC: the World Bank/ www.worldbank.org/research/growth/GDNdata.htm

Key data from WIR Annex Tables: www.unctad.org/wir.

[67] UNCTAD, Economic Development in Africa: Rethinking the Role of Foreign Direct Investment, New York and Geneva: the United Nations, (2005).

[68] UNCTAD, World Investment Report. Transnational Extractive Industrial Firms and Development Geneva : UNCTAD (2007). 
[69] Wei, S.-J., How Taxing is Corruption on Internal Investors?, The Review of Economics and Statistics, 82(1): (2000) 1-11.

[70] Wheeler, D. and A. Mody, International Investment Location Decisions: The Case of U.S. Firms », Journal of International Economics, 33, (1992) 57-76. 